\title{
Lead and nutrient allocation in vegetables grown in soil from a battery site
}

\section{Alocação de chumbo e nutrientes em hortaliças cultivadas em solo contaminado por baterias}

\author{
Francisco de Sousa Lima ${ }^{1 *}$; Clístenes Williams Araújo do Nascimento²; \\ Carla da Silva Sousa ${ }^{1}$
}

\begin{abstract}
The steady growth of the Brazilian automotive industry and the resulting development of the battery market, which represent a large proportion of the lead $(\mathrm{Pb})$ used in the country, have made battery recycling one of the main sources of $\mathrm{Pb}$ soil contamination in Brazil. Plants cultivated in $\mathrm{Pb}-$ contaminated soil can take up this metal, which can affect the plant's nutritional metabolism. The $\mathrm{Pb}$ can also be transferred into the edible parts of plants, thereby imposing threats to human health. This study was conducted to evaluate the concentration of $\mathrm{Pb}$ in edible parts of vegetables grown on soil contaminated by battery recycling activities. This study also investigated the effects of $\mathrm{Pb}$ on nutrient concentrations in plants. Plant species biomass, $\mathrm{Pb}$ concentration, and concentrations of macronutrients $(\mathrm{P}, \mathrm{K}, \mathrm{Ca}, \mathrm{Mg}$ ) and micronutrients $(\mathrm{Fe}, \mathrm{Mn}, \mathrm{Zn}, \mathrm{Cu})$ in plant parts were measured. The results showed that $\mathrm{Pb}$ concentrations in the edible parts of vegetables grown in contaminated soil were above the threshold acceptable for human consumption. Among the vegetables evaluated, only lettuce dry matter production was reduced because of the high concentration of $\mathrm{Pb}$ in soil. The presence of $\mathrm{Pb}$ altered the concentration of micronutrients in the edible parts of kale, carrots, and okra, stimulating higher $\mathrm{Mn}$ and $\mathrm{Cu}$ concentrations in these plants when cultivated in contaminated soil.
\end{abstract}

Key words: Edible parts, heavy metals, nutrients uptake

\section{Resumo}

O pleno crescimento brasileiro da indústria automobilística e a concomitante ampliação do mercado de baterias, que utiliza grande quantidade do $\mathrm{Pb}$ consumido no país, tornaram a sua reciclagem uma das principais formas de contaminação dos solos por chumbo. Plantas cultivadas em solo contaminado por $\mathrm{Pb}$ podem absorver esse metal que, além de afetar o metabolismo nutricional, pode ser transferido às partes comestíveis dos vegetais afetando a saúde humana. $\mathrm{O}$ presente trabalho objetivou avaliar o efeito do $\mathrm{Pb}$ na concentração de nutrientes em olerícolas, bem como o potencial de transferência desse elemento de um solo contaminado pela reciclagem de baterias automotivas às partes comestíveis das hortaliças. Os resultados demonstraram que, com relação as concentrações de $\mathrm{Pb}$ observadas nas partes comestíveis dos vegetais crescidos em solos contaminados, todos os vegetais apresentaram concentrações de $\mathrm{Pb}$ acima do limite aceitável para consumo humano. Entre os vegetais avaliados, somente a alface reduziu a produção de matéria seca devido a alta concentração de $\mathrm{Pb}$ no solo. Chumbo alterou a concentração de micronutrientes nas partes comestíveis, estimulando o aumento do teor de $\mathrm{Mn}$ e $\mathrm{Cu}$ em couve, cenoura e quiabo cultivados em solo contaminado.

Palavras-chave: Partes comestíveis, metais pesados, absorção de nutrientes

${ }^{1}$ Profs., Instituto Federal de Educação, Ciência e Tecnologia Baiano, IFBaiano, Valença, BA, Brasil. E-mail: fsousalima@yahoo. com.br; cssagro@yahoo.com.br

2 Prof., Dept ${ }^{\circ}$ de Agronomia, Universidade Federal Rural de Pernambuco, UFRPE, Recife, PE, Brasil. E-mail: cwanascimento@ yahoo.com

* Author for correspondence 


\section{Introduction}

Heavy metals naturally occur in low concentrations in soils, as a result of weathering and other pedogenetic processes. However, these concentrations can be amplified by biogeochemical processes and especially by anthropogenic activities (KEDE et al., 2008; FREITAS et al., 2009). Among the main environmental contaminants, lead $(\mathrm{Pb})$ is the second most hazardous element on the EPA priority list (ATSDR 2010) and poses a significant threat because of its high toxicity (YADAV et al., 2002; WANG et al., 2006; KEDE et al., 2008).

Plants grown in contaminated soils can absorb and accumulate heavy metals (LUI et al., 2006), resulting in photosynthesis inhibition, alterations in the plant structure and permeability of the membrane, and disturbances in mineral nutrition (SARMA et al., 2006). $\mathrm{Pb}$ can decrease cation ( $\mathrm{K}, \mathrm{Ca}, \mathrm{Mg}, \mathrm{Mn}$, $\mathrm{Zn}, \mathrm{Cu}, \mathrm{Fe}$ ) and anion $\left(\mathrm{NO}_{3}^{-}\right)$absorption by the root system (SHARMA; DUBEY, 2005).

Increased $\mathrm{Pb}$ concentrations in vegetable crops can be harmful to humans (RATTAN et al., 2005). Impaired cognitive development and intellectual performance in children have been associated with high levels of $\mathrm{Pb}$ consumption. Adults can suffer from reproductive and renal problems, as well as increased blood pressure (WHO, 1993). Babies can ingest $\mathrm{Pb}$ through breast-feeding, and in pregnant women, $\mathrm{Pb}$ is easily transferred to unborn babies through the placenta (RABINOWITZ et al., 1985).

The existing use of $\mathrm{Pb}$-contaminated soil to grow vegetable crops provides an ideal setting to study the $\mathrm{Pb}$ uptake potential of different vegetable species. The greater the $\mathrm{Pb}$ transfer into edible parts, the greater the risk is to consumers. This study evaluated the concentration of $\mathrm{Pb}$ in the edible parts of vegetables grown on soil contaminated by battery recycling activities and also investigated the effects of $\mathrm{Pb}$ on the concentration of nutrients in plants.

\section{Materials and Methods}

The experiment was conducted in a greenhouse between May and July 2008 using soil classified as a distrofic Spodosol, collected near an automobile battery recycling facility. The site is located in Rio Tinto, Paraiba state, Northeast Brazil (latitude $6^{\circ} 48^{\prime} 21.48^{\prime \prime} \mathrm{N}$ and longitude $35^{\circ} 04^{\prime} 32.14{ }^{\prime \prime} \mathrm{W}$ ). Samples of the same soil type were also collected from a non-contaminated area for use as a control. For the chemical and physical analyses, the soil samples were air-dried and sieved through a $2 \mathrm{~mm}$ mesh sieve (EMBRAPA, 1997, 1999) (Table 1). The total $\mathrm{Pb}$ concentration was obtained by aqua regia $\left(\mathrm{HCl}: \mathrm{HNO}_{3}\right.$, molar ratio 3:1) The aqua regia extractant was added to the soil sample and the mixture was left at room temperature in a beaker covered with a watch glass for $16 \mathrm{~h}$. The samples were then heated to $80^{\circ} \mathrm{C}$ for $2 \mathrm{~h}$, cooled, brought to $50 \mathrm{~mL}$ in a volumetric flask, and filtered (PEREIRA et al., 2007). After filtering, the extracts were transferred to PET flasks, labeled, and kept at $4{ }^{\circ} \mathrm{C}$ in a refrigerator until they were placed in an atomic absorption spectrophometer. Soil acidity was very high ( $\mathrm{pH}$ 3.9) and was therefore adjusted to a $\mathrm{pH}$ of approximately 6.5 using calcium carbonate and magnesium oxide (3:1 molar ratio).

The four vegetables chosen for this study are among the most abundant ones in the typical Brazilian diet, and represent different edible parts (tubers, leaves, and fruits). Seedlings of carrot (Daucos carota L.), kale (Brassica oleracea L. var. acephala), okra (Abelmoschus esculentus L.), and lettuce (Lactuca sativa L.) were grown in polystyrene trays in a greenhouse, using vermicompost as the substrate. To prepare the experiment, $5.5 \mathrm{~kg}$ of soil was transferred into plastic pots and fertilized prior to seedling planting. The soil samples were fertilized as follows: 250, 240, 150, and $100 \mathrm{mg} \mathrm{kg}^{-1}$ of N, P, K, and $\mathrm{S}$, respectively, added as $\mathrm{NH}_{4} \mathrm{SO}_{2}, \mathrm{NH}_{4} \mathrm{H}_{2} \mathrm{PO}_{4}$, and $\mathrm{KNO}_{3}$; the micronutrients $\mathrm{Fe}\left(\mathrm{FeSO}_{4} \cdot 7 \mathrm{H}_{2} \mathrm{O}\right)$, $\mathrm{Mn}\left(\mathrm{MnCl}_{2} \cdot 4 \mathrm{H}_{2} \mathrm{O}\right), \mathrm{Zn}\left(\mathrm{ZnSO}_{4} \cdot 7 \mathrm{H}_{2} \mathrm{O}\right), \mathrm{Cu}\left(\mathrm{CuSO}_{4}\right)$, 
$\mathrm{B}\left(\mathrm{H}_{3} \mathrm{BO}_{3}\right)$, and $\mathrm{Mo}\left(\mathrm{Na}_{2} \mathrm{MoO}_{4} \cdot 2 \mathrm{H}_{2} \mathrm{O}\right)$ were applied at the concentrations of $2,4,4,1.5,1$, and $0.2 \mathrm{mg}$ $\mathrm{kg}^{-1}$, respectively (NASCIMENTO et al., 2006). Twenty days after sowing, the seedlings were transferred into the pots, and 15 days later, they were thinned out, leaving four plants per pot. During the experiment, pots were irrigated daily with distilled water to maintain the soils at approximately $80 \%$ of water retention capacity.

Table 1. Chemical and physical characteristics of the Pb-contaminated and non-contaminated soil samples used for growing the vegetables.

\begin{tabular}{lcc}
\hline \multirow{2}{*}{ Characteristic } & & Soil \\
\cline { 2 - 3 } & Contaminated & Non-contaminated \\
\hline $\mathrm{pH}($ water $-1: 2,5)$ & 3.89 & 5.1 \\
$\mathrm{P}\left(\mathrm{mg} \mathrm{dm}^{-3}\right)$ & 2.30 & 8.30 \\
$\mathrm{Na}^{+}\left(\mathrm{cmol}_{\mathrm{c}} \mathrm{dm}^{-3}\right)$ & 0.28 & 0.31 \\
$\mathrm{~K}^{+}\left(\mathrm{cmol}_{\mathrm{c}} \mathrm{dm}^{-3}\right)$ & 0.05 & 0.10 \\
$\mathrm{Ca}^{+2}\left(\mathrm{cmol}_{\mathrm{c}} \mathrm{dm}^{-3}\right)$ & 4,6 & 4,4 \\
$\mathrm{Mg}^{+2}\left(\mathrm{cmol}_{\mathrm{c}} \mathrm{dm}^{-3}\right)$ & 0.90 & 2.90 \\
$\mathrm{Al}$ & 0.50 & 0.15 \\
$\left.\mathrm{H}+\mathrm{cmol}_{\mathrm{c}} \mathrm{dm}^{-3}\right)$ & 3.30 & 2.80 \\
$\mathrm{~Pb}\left(\mathrm{mg} \mathrm{kg}_{\mathrm{c}} \mathrm{dm}^{-3}\right)$ & 413.0 & 9.20 \\
$\mathrm{M} . \mathrm{O}\left(\mathrm{g} \mathrm{kg}^{-1}\right)$ & 14.73 & 26.9 \\
$\mathrm{Sand}\left(\mathrm{g} \mathrm{kg}^{-1}\right)$ & 943.0 & 940.0 \\
Silt $\left(\mathrm{g} \mathrm{kg}^{-1}\right)$ & 27.0 & 27.0 \\
Clay $\left(\mathrm{g} \mathrm{kg}^{-1}\right)$ & 30.0 & 33.0 \\
\hline
\end{tabular}

The experiment was conducted in a factorial randomized blocks design of $2 \times 4 \times 4$. The treatments consisted of two soil conditions (contaminated and non-contaminated), four vegetable species (lettuce, kale, carrot, and okra) and four plant parts (root, stem, leaf, and edible parts), with four replications. The plants were separated into roots, stems, leaves, and edible parts, washed thoroughly in tap water, and then in distilled water, to remove traces of nutrients and $\mathrm{Pb}$ ions from the surface (LIU et al., 2009). The collected parts were weighed, put in paper bags, and dried in an oven at $65-70^{\circ} \mathrm{C}$ until they reached a constant weight. The dried samples were weighed once more, ground in a Wiley cutting mill, and were then submitted to a nitro-perchloric digestion (EMBRAPA, 1999) to determine concentrations of $\mathrm{Ca}, \mathrm{Mg}, \mathrm{Fe}, \mathrm{Mn}, \mathrm{Zn}, \mathrm{Cu}$, and $\mathrm{Pb}$ by atomic absorption spectrophotometry, P by colorimetry, and $\mathrm{K}$ by flame photometry. Soil samples from each pot were taken to measure available $\mathrm{Pb}$ by EDTA and DTA (LINDSAY; NORVELL, 1978; LANTMANN; MEURER, 1982). The data obtained for dry matter, $\mathrm{Pb}$ content, and concentrations of macro and micronutrients in the various plant parts were submitted to analysis of variance (ANOVA) and the measurements were compared using the Scott-Knot test at 5\% probability. Using the same soil used in our experiment, Freitas et al. (2014) reported that lime amendment decreased the soluble amounts of $\mathrm{Pb}$ in soil from up to $361 \mathrm{mg} \mathrm{L}^{-1}$ to 168 $\mathrm{mg} \mathrm{L^{-1 }}$.

\section{Results and Discussion}

The presence of $\mathrm{Pb}$ significantly altered the production of leaf and edible part dry matter for plants grown in contaminated soil, but had no apparent effect on the production of root dry matter 
for any of the vegetable species studied (Table 2). For lettuce, a $14.55 \%$ reduction was observed in the dry matter production of leaves. Okra plants showed greater production of fruit dry matter when grown in $\mathrm{Pb}$-contaminated soil. Considering the strong adsorptive capacity of $\mathrm{Pb}$ by iron oxides, clay minerals, and organic matter (BOSSO;
ENZWEILER, 2008), the reduced phytotoxic effects of $\mathrm{Pb}$ in the soil indicate that the overall high soil concentrations do not necessarily imply high toxicity of plants. Additionally, adjusting the $\mathrm{pH}$ to approximately 6.5 probably contributed to decreased $\mathrm{Pb}$ availability in the soil.

Table 2. Dry matter production ( $\mathrm{g}^{-1}$ per pot) for vegetables grown in Pb-contaminated and non-contaminated soils.

\begin{tabular}{ccccccccc}
\hline Part & \multicolumn{2}{c}{ Lettuce } & \multicolumn{2}{c}{ Kale } & \multicolumn{2}{c}{ Carrot } & \multicolumn{2}{c}{ Okra } \\
\cline { 2 - 8 } Soil & $\mathrm{C}$ & $\mathrm{NC}$ & $\mathrm{C}$ & $\mathrm{NC}$ & $\mathrm{C}$ & $\mathrm{NC}$ & $\mathrm{C}$ & $\mathrm{NC}$ \\
\hline Root & $0.43 \mathrm{Ac}$ & $1.01 \mathrm{Ac}$ & $2.71 \mathrm{Ac}$ & $2.02 \mathrm{Ac}$ & $0.75 \mathrm{Ac}$ & $0.54 \mathrm{Ac}$ & $1.45 \mathrm{Ac}$ & $1.55 \mathrm{Ac}$ \\
Stem & $2.18 \mathrm{Ab}$ & $3.70 \mathrm{Ab}$ & $4.56 \mathrm{Ab}$ & $4.54 \mathrm{Ab}$ & $\mathrm{NA}$ & $\mathrm{NA}$ & $2.98 \mathrm{Ab}$ & $4.11 \mathrm{Ab}$ \\
Leaf & $9.45 \mathrm{Ba}$ & $11.06 \mathrm{Aa}$ & $14.28 \mathrm{Aa}$ & $13.28 \mathrm{Ba}$ & $14.82 \mathrm{Aa}$ & $13.08 \mathrm{Ba}$ & $6.67 \mathrm{Aa}$ & $7.54 \mathrm{Aa}$ \\
Edible part & $*$ & $*$ & $*$ & $*$ & $3.93 \mathrm{Ab}$ & $2.51 \mathrm{Ab}$ & $6.54 \mathrm{Aa}$ & $3.86 \mathrm{Bb}$ \\
\hline Total & $12.07 \mathrm{~B}$ & $15.77 \mathrm{~A}$ & $22.25 \mathrm{~A}$ & $19.84 \mathrm{~B}$ & $19.51 \mathrm{~A}$ & $16.14 \mathrm{~B}$ & $17.64 \mathrm{~A}$ & $17.06 \mathrm{~A}$ \\
\hline CV $\%$ & & \multicolumn{7}{c}{17.05} \\
\hline
\end{tabular}

$*=$ Leaf itself is the edible part.

$\mathrm{C}=$ contaminated soil; $\mathrm{NC}=$ non-contaminated soil; $\mathrm{NA}=$ non-applicable.

Means followed by the same letters are not significantly different by the Scott \& Knott test at $5 \%$ probability. Capital letters compares plant parts, between a contaminated and a non-contaminated soil; small letters compares each plant part for each soil condition.

The $\mathrm{Pb}$ concentrations in the edible parts of vegetables grown in contaminated soil varied between 1.03 and $26.19 \mathrm{mg} \mathrm{kg}^{-1}$ of dry matter, in the following order: carrot $>$ okra $>$ lettuce $>$ kale (Figure 1). Carrot, despite having only $20.15 \%$ of matter in the edible parts (Table 2), had the greatest potential to transfer $\mathrm{Pb}$ from the soil into the food chain because of the high concentrations of this metal in the edible parts. The edible parts of kale cultivated in contaminated soil had the highest dry weight compared to the weights of the other plant parts (Table 2). However, kale had the lowest accumulation of $\mathrm{Pb}$ among the crops, and it also transferred the lowest quantity of $\mathrm{Pb}$ from the soil to the plant (Figure 1). Kale concentrated only $1.03 \mathrm{mg}$ $\mathrm{kg}^{-1}$ of $\mathrm{Pb}$ in its edible parts, and because of the high quantity of dry matter produced (Table 2), it did not extract significant amounts of $\mathrm{Pb}$ from the soil.

Figure 1. $\mathrm{Pb}$ concentration $\left(\mathrm{mg} \mathrm{kg}^{-1}\right)$ and content $\left(\mathrm{mg} \mathrm{pot}^{-1}\right)$ in edible plant parts grown in contaminated soil. Means followed by the same letters are not significantly different by the Scott \& Knott test at $5 \%$ probability.
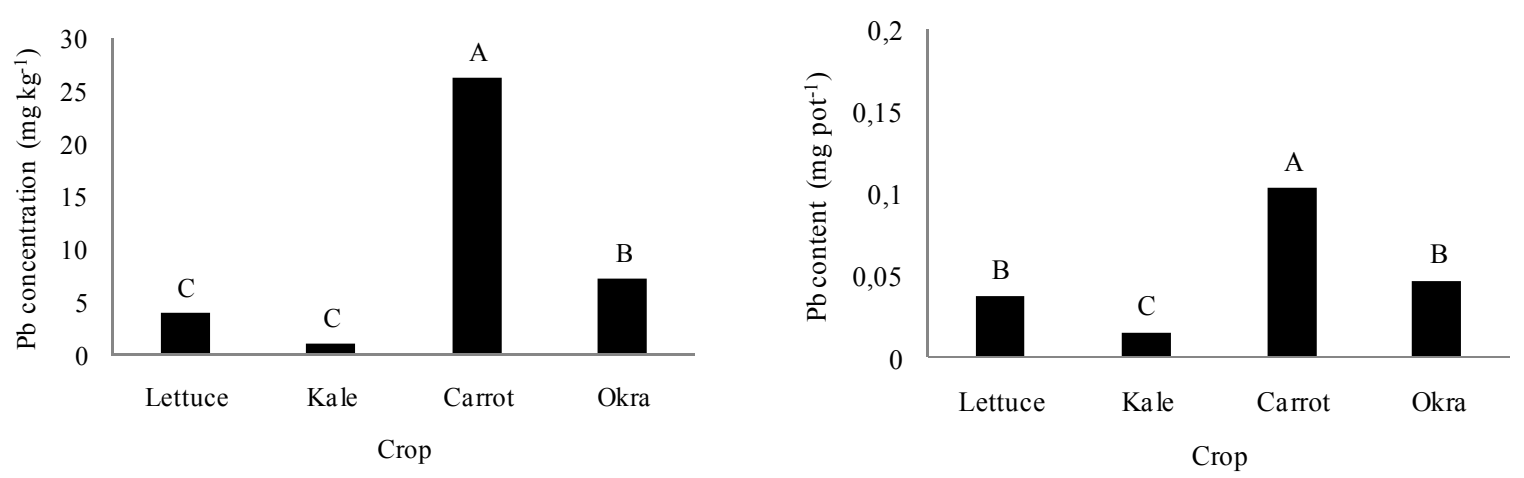
The high concentrations of $\mathrm{Pb}$ in the edible parts of the vegetable species (lettuce: $2.01 \mathrm{mg} \mathrm{kg}^{-1} \mathrm{FW}$; kale: $0.56 \mathrm{mg} \mathrm{kg}^{-1} \mathrm{FW}$; carrot: $14.17 \mathrm{mg} \mathrm{kg}^{-1} \mathrm{FW}$; and okra: $3.97 \mathrm{mg} \mathrm{kg}^{-1} \mathrm{FW}$ ) are above the allowable legal limits for healthy human consumption, according to Codex Alimentarius, 2014. Even though the $\mathrm{Pb}$ concentrations were higher than those permitted for agricultural soils according to Brazilian regulations (CONAMA, 2014), the vegetables contained acceptable and different amounts of $\mathrm{Pb}$ in their edible parts (Figure 1). This indicates that $\mathrm{Pb}$ transfer to these parts is highly dependent on species.

The presence of $\mathrm{Pb}$ in the soil reduced the concentration of $\mathrm{Ca}$ in lettuce (Table 3). The presence of $\mathrm{Pb}$ generates antagonism in terms of $\mathrm{Ca}$ absorption, inhibiting this function because of the blocking of cationic channels through competitive transport (SHARMA; DUBEY 2005; LIU et al., 2009). However, the presence of $\mathrm{Pb}$ in the soil prompted increased $\mathrm{Ca}$ concentrations in kale and carrot roots. No significant effect of $\mathrm{Pb}$ on the concentration of this element was found for the other vegetable parts. $\mathrm{Pb}$ can affect the natural processes of absorption and translocation of nutrients in plants grown in contaminated soil (SINHA et al., 2006; GOPAL; RIZVI, 2008), possibly by altering the selectivity and permeability of the plasma membrane. This can apply to increased uptake of some elements, especially for those absorbed by passive routes (SHARMA; DUBEY, 2005; LIU et al., 2009; SARMA et al., 2006), thereby contributing, in some cases, to increased concentrations of certain nutrients in plants.

The presence of $\mathrm{Pb}$ in the soil increased the concentration of $\mathrm{Mg}$ in lettuce stems, kale leaves, and carrot roots (Table 3). However, $\mathrm{Pb}$ did not affect $\mathrm{Mg}$ concentrations in lettuce, carrot, and okra leaves. Díaz-Aguilar et al. (2001) reported that $\mathrm{Pb}$ did not affect $\mathrm{Mg}$ concentrations in wheat leaves grown in soil with a high $\mathrm{Pb}$ concentration.

$\mathrm{Pb}$ caused significant increases in $\mathrm{P}$ concentrations in kale and carrot roots, although the concentration of this element was lower in kale and okra leaves (Table 3). Some authors (GOPAL; RIZVI, 2008) have observed that the presence of $\mathrm{Pb}$ provokes synergism in $\mathrm{P}$ absorption in radish plants, because of the direct interference of this metal with the metabolism of $\mathrm{P}$ in the plant. It is also likely that $\mathrm{P}$ added via fertilization can precipitate $\mathrm{Pb}$ by forming lead phosphates in the roots (MUÑOZBERTOMEU et al., 2009).

Except for the edible parts of carrots, the presence of $\mathrm{Pb}$ altered $\mathrm{K}$ concentrations in all plant parts for plants grown in contaminated and noncontaminated soils (Table 3 ). $\mathrm{Pb}$ promoted reduction in $\mathrm{K}$ concentrations in lettuce roots, although the opposite condition was observed in other vegetable parts. This increase in $\mathrm{K}$ concentrations in plant parts may be related to the loss of selectivity in cellular membranes (SARMA et al., 2006) provoked by $\mathrm{Pb}$, thereby favoring the passive uptake of $\mathrm{K}$. This may be the reason for the increased concentration of $\mathrm{K}$ in plant aerial parts, i.e., the increase in the root $\mathrm{K}$ uptake was probably related to $\mathrm{K}$ redistribution in plants.

$\mathrm{K}$ concentrations in plant parts grown in contaminated soil varied from 13.58 to $55.51 \mathrm{mg}$ $\mathrm{kg}^{-1}$ (lettuce), 22.60 to $50.91 \mathrm{mg} \mathrm{kg}^{-1}$ (kale), 15.95 to $36.72 \mathrm{mg} \mathrm{kg}^{-1}$ (carrot), and 33.23 to 44.29 (okra) (Table 3). K was concentrated mainly in the leaves of the plants, except in the case of okra. The okra plants grown in contaminated soil contained the greatest $\mathrm{K}$ concentrations in their stems, at 1.41 times the amount found in the fruit, reflecting low transfer of this element to edible plant parts. 
Table 3. $\mathrm{Ca}, \mathrm{Mg}, \mathrm{P}$ and $\mathrm{K}$ concentration in lettuce, kale, carrot and okra, grown in $\mathrm{Pb}$-contaminated and noncontaminated soil.

\begin{tabular}{|c|c|c|c|c|c|c|c|c|}
\hline Crop & \multicolumn{2}{|c|}{ Lettuce } & \multicolumn{2}{|c|}{ Kale } & \multicolumn{2}{|c|}{ Carrot } & \multicolumn{2}{|c|}{ Okra } \\
\hline & $\mathrm{C}$ & $\mathrm{NC}$ & $\mathrm{C}$ & $\mathrm{NC}$ & $\mathrm{C}$ & $\mathrm{NC}$ & $\mathrm{C}$ & $\mathrm{NC}$ \\
\hline \multicolumn{9}{|c|}{$\mathrm{Ca}\left(\mathrm{g} \mathrm{kg}^{-1}\right)$} \\
\hline Root & $9.09 \mathrm{Bb}$ & $12,66 \mathrm{Ab}$ & $13,55 \mathrm{Ab}$ & $3,97 \mathrm{Bb}$ & $15,41 \mathrm{Aa}$ & $12,29 \mathrm{Bb}$ & $13,27 \mathrm{Ab}$ & $13,28 \mathrm{Ab}$ \\
\hline Stem & $5.80 \mathrm{Bc}$ & $14,06 \mathrm{Ab}$ & $3,74 \mathrm{Ac}$ & $3,51 \mathrm{Ab}$ & NA & NA & $14,29 \mathrm{Ab}$ & $14,39 \mathrm{Ab}$ \\
\hline Leaf & $14.72 \mathrm{Ba}$ & $18.77 \mathrm{Aa}$ & $17.88 \mathrm{Aa}$ & $17.31 \mathrm{Aa}$ & $16.19 \mathrm{Aa}$ & $16.40 \mathrm{Aa}$ & 40.39Aa & $42.02 \mathrm{Aa}$ \\
\hline $\begin{array}{r}\text { Edible } \\
\text { plant }\end{array}$ & $*$ & $*$ & $*$ & $*$ & $3.92 \mathrm{Ab}$ & $3.75 \mathrm{Ac}$ & $4.42 \mathrm{Ac}$ & 4.46Ac \\
\hline $\begin{array}{r}* \mathrm{CV} \\
(\%) \\
\end{array}$ & \multicolumn{8}{|c|}{10.23} \\
\hline \multicolumn{9}{|c|}{$\operatorname{Mg}\left(\mathrm{g} \mathrm{kg}^{-1}\right)$} \\
\hline Root & $33.52 \mathrm{Ab}$ & $35.92 \mathrm{Ab}$ & $16.94 \mathrm{Ab}$ & $15.96 \mathrm{Ab}$ & 52.39Aa & $39.70 \mathrm{Ba}$ & $34.62 \mathrm{Ac}$ & $34.93 \mathrm{Ac}$ \\
\hline Stem & $38.69 \mathrm{Aa}$ & $17.89 \mathrm{Bc}$ & $15.87 \mathrm{Ab}$ & $15.80 \mathrm{Ab}$ & NA & $\mathrm{NA}$ & $39.01 \mathrm{Ab}$ & $38.50 \mathrm{Ab}$ \\
\hline Leaf & $41.27 \mathrm{Aa}$ & 42.08Aa & $39.10 \mathrm{Aa}$ & $35.27 \mathrm{Ba}$ & $34.35 \mathrm{Ab}$ & $31.95 \mathrm{Ab}$ & 53.48Aa & $54.56 \mathrm{Aa}$ \\
\hline $\begin{array}{c}\text { Edible } \\
\text { plant }\end{array}$ & $*$ & $*$ & $*$ & $*$ & $18.48 \mathrm{Bc}$ & $26.78 \mathrm{Ac}$ & $29.10 \mathrm{Ac}$ & 30.74Ad \\
\hline $\begin{array}{c}* \mathrm{CV} \\
(\%)\end{array}$ & \multicolumn{8}{|c|}{19.93} \\
\hline \multicolumn{9}{|c|}{$\mathrm{P}\left(\mathrm{g} \mathrm{kg}^{-1}\right)$} \\
\hline Root & $15.25 \mathrm{Aa}$ & $13.83 \mathrm{Aa}$ & $13.22 \mathrm{Aa}$ & $8.36 \mathrm{Bb}$ & $12.08 \mathrm{Aa}$ & $9.54 \mathrm{Ba}$ & 8.80Aa & 9.21Aa \\
\hline Stem & $8.93 \mathrm{Ab}$ & $8.33 \mathrm{Ab}$ & $6.13 \mathrm{Ac}$ & $6.40 \mathrm{Ac}$ & NA & $\mathrm{NA}$ & $5.94 \mathrm{Ab}$ & $6.06 \mathrm{Ab}$ \\
\hline Leaf & $7.63 \mathrm{Ab}$ & $8.23 \mathrm{Ab}$ & $11.60 \mathrm{Bb}$ & $15.40 \mathrm{Aa}$ & $7.52 \mathrm{Ab}$ & 7.48Ab & $8.25 \mathrm{Ba}$ & 9.99Aa \\
\hline $\begin{array}{l}\text { Edible } \\
\text { plant }\end{array}$ & $*$ & $*$ & $*$ & $*$ & $6.73 \mathrm{Ab}$ & 6.97Ab & $6.28 \mathrm{Ab}$ & $6.33 \mathrm{Ab}$ \\
\hline $\begin{array}{r}* \mathrm{CV} \\
(\%)\end{array}$ & \multicolumn{8}{|c|}{18.78} \\
\hline \multicolumn{9}{|c|}{$\mathrm{K}\left(\mathrm{g} \mathrm{kg}^{-1}\right)$} \\
\hline Root & $13.58 \mathrm{Bc}$ & $22.10 \mathrm{Ac}$ & $22.60 \mathrm{Ab}$ & $17.80 \mathrm{Bb}$ & $15.95 \mathrm{Ac}$ & $6.90 \mathrm{Bb}$ & $35.71 \mathrm{Ab}$ & $28.91 \mathrm{Ba}$ \\
\hline Stem & $35.01 \mathrm{Ab}$ & $30.72 \mathrm{Bb}$ & 50.91Aa & $31.13 \mathrm{Ba}$ & NA & $\mathrm{NA}$ & 44.29Aa & $29.05 \mathrm{Ba}$ \\
\hline Leaf & $55.51 \mathrm{Aa}$ & $46.58 \mathrm{Ba}$ & $50.19 \mathrm{Aa}$ & $30.76 \mathrm{Ba}$ & $36.72 \mathrm{Aa}$ & $30.86 \mathrm{Ba}$ & $33.23 \mathrm{Ac}$ & $27.32 \mathrm{Ba}$ \\
\hline $\begin{array}{r}\text { Edible } \\
\text { plant }\end{array}$ & $*$ & $*$ & $*$ & $*$ & $28.00 \mathrm{Ab}$ & $27.71 \mathrm{Aa}$ & 31.37Ac & 27.32Ba \\
\hline $\begin{array}{c}* \mathrm{CV} \\
(\%)\end{array}$ & \multicolumn{8}{|c|}{10.72} \\
\hline
\end{tabular}

$*=$ Leaf itself is the edible part.

$\mathrm{C}=$ contaminated soil; $\mathrm{NC}=$ non-contaminated soil; $\mathrm{NA}=$ non-applicable.

$* \mathrm{CV}=$ Coefficient of Variation.

Means followed by the same letters are not significantly different by the Scott \& Knott test at $5 \%$ probability. Capital letters in the line compare the same crop and the same plant part; small letters in the column compares parts of same crop for each soil condition.

$\mathrm{Pb}$ increased $\mathrm{Fe}$ concentrations in the roots of lettuce, kale, carrot, and okra. However, concentrations of $\mathrm{Fe}$ were $18 \%$ lower in the leaves of lettuce cultivated in contaminated soil (Table 4). Cabbage plants grown in $\mathrm{Pb}$-contaminated soil showed reduced concentrations of $\mathrm{Fe}$ in the leaves (SINHA et al., 2006). The Fe reduction in leaves results in a loss of vitality and capacity to resist stressful conditions (GEEBELEN et al., 2002). An increase in $\mathrm{Fe}$ concentrations in roots was also noted by Gopal and Rizvi (2008) who evaluated alterations to radish plants submitted to excess $\mathrm{Pb}$. The increase in $\mathrm{Fe}$ concentrations in the roots may be caused by higher $\mathrm{Fe}$ flow resulting from $\mathrm{Pb}$ - 
induced loss of membrane selectivity (SHARMA; DUBEY, 2005).

A high concentration of $\mathrm{Mn}$ was recorded in the roots and stems of plants grown in contaminated soil (Table 4). In contrast with Pb-induced low concentration of $\mathrm{Mn}$ in lettuce leaves, kale and okra leaves grown in contaminated soil displayed greater concentrations of this metal. Mn was mainly concentrated in the leaves of all the plants. The presence of $\mathrm{Pb}$ in the soil also increased
Mn concentrations in wheat plant parts (DÍAZAGUILAR et al., 2001).

Although $\mathrm{Pb}$ prompted an increase in $\mathrm{Zn}$ concentrations in lettuce roots grown in contaminated soil, a $28.50 \%$ reduction was noted in the concentration of $\mathrm{Zn}$ in lettuce leaves (Table 4). The low concentration of $\mathrm{Zn}$ in leaves is related to the reduction in the stability of the plasma membrane, thus making plants less tolerant to biotic stresses such as metal toxicity (GEEBELEN et al., 2002).

Table 4. Concentration of $\mathrm{Fe}, \mathrm{Mn}, \mathrm{Zn}$ and $\mathrm{Cu}$ in lettuce, kale, carrot and okra grown in Pb-contaminated and noncontaminated soil.

\begin{tabular}{|c|c|c|c|c|c|c|c|c|}
\hline \multirow{2}{*}{$\frac{\text { Crop }}{\text { Soil }}$} & \multicolumn{2}{|c|}{ Lettuce } & \multicolumn{2}{|c|}{ Kale } & \multicolumn{2}{|c|}{ Carrot } & \multicolumn{2}{|c|}{ Okra } \\
\hline & $\mathrm{C}$ & $\mathrm{NC}$ & $\mathrm{C}$ & $\mathrm{NC}$ & $\mathrm{C}$ & $\mathrm{NC}$ & $\mathrm{C}$ & $\mathrm{NC}$ \\
\hline \multicolumn{9}{|c|}{$\mathrm{Fe}\left(\mathrm{mg} \mathrm{kg}^{-1}\right)$} \\
\hline Root & $233.15 \mathrm{Aa}$ & $189.60 \mathrm{Ba}$ & $244.57 \mathrm{Aa}$ & $149.93 \mathrm{Ba}$ & $268.92 \mathrm{Aa}$ & $149.31 \mathrm{Ba}$ & $235.57 \mathrm{Aa}$ & $133.70 \mathrm{Ba}$ \\
\hline Stem & $43.11 \mathrm{Ac}$ & $52.57 \mathrm{Ac}$ & $21.01 \mathrm{Ac}$ & $27.05 \mathrm{Ac}$ & NA & $\mathrm{NA}$ & $26.20 \mathrm{Ac}$ & $25.52 \mathrm{Ad}$ \\
\hline Leaf & $136.41 \mathrm{Bb}$ & $167.06 \mathrm{Ab}$ & 83.89Ab & $85.02 \mathrm{Ab}$ & $71.51 \mathrm{Ab}$ & 76.90Bb & $74.88 \mathrm{Ab}$ & $85.92 \mathrm{Ab}$ \\
\hline $\begin{array}{c}\text { Edible } \\
\text { part }\end{array}$ & $*$ & * & $*$ & $*$ & $48.51 \mathrm{Ac}$ & 51.89Ac & $36.34 \mathrm{Ac}$ & $47.16 \mathrm{Ac}$ \\
\hline${ }^{*} \mathrm{CV}(\%)$ & & & & & .22 & & & \\
\hline \multicolumn{9}{|c|}{$\mathrm{Mn}\left(\mathrm{mg} \mathrm{kg}^{-1}\right)$} \\
\hline Root & $77.23 \mathrm{Ab}$ & $35.89 \mathrm{Bb}$ & $144.45 \mathrm{Aa}$ & $16.28 \mathrm{Bb}$ & 525.19Aa & $128.98 \mathrm{Ba}$ & $103.57 \mathrm{Ab}$ & $40.46 \mathrm{Bb}$ \\
\hline Stem & $30.73 \mathrm{Ac}$ & $14.61 \mathrm{Bc}$ & $13.95 \mathrm{Ab}$ & $4.64 \mathrm{Bc}$ & $\mathrm{NA}$ & $\mathrm{NA}$ & 39.90Ac & $18.52 \mathrm{Bc}$ \\
\hline Leaf & $126.49 \mathrm{Ba}$ & $270.04 \mathrm{Aa}$ & $142.12 \mathrm{Aa}$ & $78.28 \mathrm{Ba}$ & $182.51 \mathrm{Ab}$ & $133.31 \mathrm{Aa}$ & $260.83 \mathrm{Aa}$ & $159.24 \mathrm{Ba}$ \\
\hline $\begin{array}{c}\text { Edible } \\
\text { part }\end{array}$ & $*$ & * & $*$ & * & 42.38Ac & $18.10 \mathrm{Bb}$ & 40.88Ac & $24.09 \mathrm{Bc}$ \\
\hline$* \mathrm{CV}(\%)$ & & & & & .46 & & & \\
\hline \multicolumn{9}{|c|}{$\mathrm{Zn}\left(\mathrm{mg} \mathrm{kg}^{-1}\right)$} \\
\hline Root & $392.82 \mathrm{Aa}$ & $188.92 \mathrm{Bb}$ & $612.54 \mathrm{Aa}$ & $227.17 \mathrm{Bb}$ & $909.97 \mathrm{Aa}$ & $253.03 \mathrm{Ba}$ & $395.91 \mathrm{Ab}$ & $255.01 \mathrm{Ba}$ \\
\hline Stem & $236.81 \mathrm{Ab}$ & $293.26 \mathrm{Aa}$ & $263.36 \mathrm{Ab}$ & $154.54 \mathrm{Bc}$ & $\mathrm{NA}$ & $\mathrm{NA}$ & 226.44Ac & $101.72 \mathrm{Bc}$ \\
\hline Leaf & $227.70 \mathrm{Bb}$ & 318.36Aa & 617.88Aa & $325.97 \mathrm{Ba}$ & $178.73 \mathrm{Ab}$ & $179.17 \mathrm{Ab}$ & 486.81Aa & $178.26 \mathrm{Bb}$ \\
\hline $\begin{array}{c}\text { Edible } \\
\text { part }\end{array}$ & $*$ & $*$ & $*$ & $*$ & $171.16 \mathrm{Ab}$ & $143.17 \mathrm{Ab}$ & $164.08 \mathrm{Ad}$ & $180.26 \mathrm{Ab}$ \\
\hline${ }^{*} \mathrm{CV}(\%)$ & & & & & .28 & & & \\
\hline \multicolumn{9}{|c|}{$\mathrm{Cu}\left(\mathrm{mg} \mathrm{kg}^{-1}\right)$} \\
\hline Root & $48.27 \mathrm{Aa}$ & $22.54 \mathrm{Ba}$ & $34.36 \mathrm{Ba}$ & 38.30Aa & $35.33 \mathrm{Aa}$ & $18.59 \mathrm{Ba}$ & 19.36Aa & 7.71Ba \\
\hline Stem & $9.96 \mathrm{Ac}$ & $10.80 \mathrm{Ac}$ & $14.49 \mathrm{Ac}$ & $14.49 \mathrm{Ab}$ & NA & NA & 5.89Ac & $2.39 \mathrm{Bb}$ \\
\hline Leaf & $13.48 \mathrm{Ab}$ & $12.98 \mathrm{Ab}$ & $19.27 \mathrm{Ab}$ & $14.49 \mathrm{Bb}$ & $8.88 \mathrm{Ab}$ & $4.14 \mathrm{Bb}$ & $8.63 \mathrm{Ab}$ & $3.64 \mathrm{Bb}$ \\
\hline $\begin{array}{c}\text { Edible } \\
\text { part }\end{array}$ & $*$ & $*$ & $*$ & $*$ & $8.13 \mathrm{Ab}$ & $4.39 \mathrm{Bb}$ & $6.14 \mathrm{Ac}$ & $1.89 \mathrm{Bb}$ \\
\hline${ }^{*} \mathrm{CV}(\%)$ & \multicolumn{8}{|c|}{8.05} \\
\hline
\end{tabular}

$*=$ Leaf itself is the edible part. $\mathrm{C}=$ contaminated soil; $\mathrm{NC}=$ non contaminated soil; $\mathrm{NA}=$ non-applicable. ${ }^{*} \mathrm{CV}=\mathrm{Coefficient}$ of Variation.

Means followed by the same letters are not significantly different by the Scott \& Knott test at 5\% probability.

Capital letters compare each plant part between a contaminated and a non-contaminated soil; and small letters compare each plant part for each soil condition. 
Similar to lettuce, greater concentrations of $\mathrm{Zn}$ were observed in kale, carrot, and okra roots grown in contaminated soil. The lettuce, kale, and carrot plants grown in contaminated soil had highest $\mathrm{Zn}$ concentrations in the roots, whereas in okra plants the highest concentrations were in the leaves.

$\mathrm{Pb}$ caused high $\mathrm{Cu}$ concentrations in lettuce, carrot, and okra roots, but was related to reductions in $\mathrm{Cu}$ concentration in kale roots (Table 4). In general, an imbalance in $\mathrm{Cu}$ allocation promoted by $\mathrm{Pb}$ was observed in plant parts, and was also reported by Sharma and Dubey (2005). It was also found that, in both contaminated and noncontaminated soils, the highest and lowest $\mathrm{Cu}$ concentrations in plant parts were observed in roots and stems, respectively. $\mathrm{Pb}$ also prompted a significant increase in the concentration of $\mathrm{Cu}$ in carrot roots, leaves, and edible parts (Table 4). The increase in $\mathrm{Cu}$ concentrations in the plant parts may be caused by higher $\mathrm{Cu}$ flow resulting from the $\mathrm{Pb}$ induced loss of membrane selectivity (SHARMA; DUBEY, 2005).

\section{Conclusions}

1. The edible parts of vegetables grown in contaminated soils all had $\mathrm{Pb}$ concentrations above the acceptable threshold for human consumption.

2. Among the vegetables evaluated, only the lettuce dry matter production was reduced because of high concentrations of soil $\mathrm{Pb}$.

3. $\mathrm{Pb}$ altered the concentration of micronutrients in the edible parts of kale, carrots, and okra, thus stimulating higher $\mathrm{Mn}$ and $\mathrm{Cu}$ concentrations in these plants when cultivated in contaminated soil.

4. In general, $\mathrm{Pb}$ toxicity changed the macronutrient concentrations and distributions in the plants. For example, although $\mathrm{P}$ root uptake increased, the amounts of P transferred to shoots decreased. This effect was probably caused by damages to the plasma membrane and precipitation of $\mathrm{Pb}$ phosphates in the roots. In contrast, $\mathrm{K}$ had increased uptake because of higher membrane permeability, as reflected by higher concentrations in other plant parts.

\section{References}

AGENCY FOR TOXIC SUBSTANCES \& DISEASE REGISTRY - ATSDR. United States department of health and human services, priority list of hazardous substances. 2010. Available at: <http://www.atsdr.cdc. gov/cercla/07list.html>. Accessed at: 30 fev. 2014.

BOSSO, S. T.; ENZWEILER, J. Ensaios para determinar o (Bio)disponibilidade de $\mathrm{Pb}$ em solos contaminados. Química Nova, São Paulo, v. 31, n. 2, p. 394-400, 2008.

CODEX ALIMENTARIUS. International food standards. 2014. Available at: <http://www.codexalimentarius.net/ web/more_info.jsp?id_sta=17>. Accessed at: $18 \mathrm{fev}$. 2014.

CONSELHO NACIONAL DO MEIO AMBIENTE CONAMA. Resolução 420/2009. Dispõe sobre critérios e valores orientadores de qualidade do solo quanto à presença de substâncias químicas e estabelece diretrizes para o gerenciamento ambiental de áreas contaminadas por essas substâncias em decorrência de atividades antrópicas. 2014. Disponível em: $<$ http://www.iusnatura. com.br/news03_arquivos/CONAMA_420_09.pdf $>$. Acesso em: 15 fev. 2014.

DÍAZ-AGUILAR, I.; LARQUE-SAAVEDRA, M. U.; ALCANTAR-GONZALEZ， G.; CARRILLOGONZALEZ, R.; VAZQUEZ-ALARCON, A. Alteration of some physiological processes in wheat by lead additions. Revista Internacional de Contaminacion Ambiental, v. 17, n. 2, p. 79-90, 2001.

EMPRESA BRASILEIRA DE PESQUISA AGROPECUÁRIA - EMBRAPA. Centro Nacional de Pesquisa de Solos. Manual de métodos de análise de solo. Centro Nacional de Pesquisa de Solos. 2. ed. Rio de Janeiro: EMBRAPA-CNPS, 1997. 212 p. (Documentos, $1)$.

Manual de análises químicas de solos, plantas e fertilizantes. Embrapa Solos. Embrapa Informática agropecuária. Organizador Fábio César da Silva. Brasília: Embrapa Comunicação para Transferência de Tecnologia de Tecnologia, 1999. 370 p.

FREITAS, E. V.; NASCIMENTO, C. W. A.; SILVA, W. M. Citric acid-assisted phytoextraction of lead in the field: the use of soil amendments. Water, Air and Soil Pollution, Dordrecht, v. 225, p. 1796, 2014. Supplement. 
FREITAS, E. V. S.; NASCIMENTO, C. W. A.; SILVA, A. J.; DUDA, G. P. Indução da fitoextração de chumbo por ácido cítrico em solo contaminado por baterias automotivas. Revista Brasileira de Ciência do Solo, Viçosa, v. 33, n. 2, p. 467-473, 2009.

GEEBELEN, W.; VANGRONSVELD, J.; ADRIANO, D. C.; POUCKEC, L. C. V.; CLIJSTERS, H. Effects of Pb-EDTA and EDTA on oxidative stress reactions and mineral uptake in Phaseolus vulgaris. Physiologia Plantarum, Sweden, v. 115, n. 3, p. 377-384, 2002.

GOPAL, R.; RIZVI, A. H. Excess lead alters growth, metabolism and translocation of certain nutrients in radish. Chemosphere, Oxford, v. 70, n. 9, p. 1539-1544, 2008.

KEDE, M. L. F.; MOREIRA, J. C.; MAVROPOULOS, E.; ROSSI, A. M.; BERTOLINO, L. C.; PEREZ, D. V.; ROCHA, N. C. C. Estudo do comportamento do chumbo em latossolos brasileiros tratados com fosfatos: contribuições para a remedição de sítios contaminados. Química Nova, São Paulo, v. 31, n. 3, p. 579-584, 2008.

LANTMANN, A. F.; MEURER, E. J. Estudo de eficiências de extratores para avaliação de zinco disponível no solo para milho. Revista Brasileira de Ciência do Solo, Viçosa, v. 6, p. 131-135, 1982.

LINDSAY, W. L.; NORVELL, W. A. Development of DTPA soil test for zinc, iron, manganese and popper. Soil Science Society of America Journal, Madison, v. 42, n. 3, p. 421-428, 1978.

LIU, D.; ZOU, J.; MENG, Q.; ZOU, J.; JIANG, W. Uptake and accumulation and oxidative stress in garlic (Allium sativum L. ) under lead phytotoxicity. Ecotoxicology, London, v. 18, n. 1, p. 134-143, 2009.

LUI, W. X.; LI, H. H.; LI, S. R.; WANG, Y. W. Heavy metal accumulation of edible vegetables cultivated in agricultural soil in the suburb of Zhengzhou city, People's Republic of China. Bulletin of Environmental Contamination and Toxicology, New York, v. 76, n. 1, p. 163-170, 2006.

MUÑOZ-BERTOMEU, J.; CASCALES-MIÑANA, B.; MULET, J. M.; BAROJA-FERNANDEZ, E.; POZUETAROMERO, J.; KUHN, J. M.; SEGURA, J.; ROS, R. Plastidial glyceraldehyde-3-phosphate dehydrogenase deficiency leads to altered root development and affects the sugar and amino acid balance in Arabidopsis. Plant Physiology, Lancaster, v. 151, n. 2, p. 541-558, 2009.
NASCIMENTO, C. W. A.; AMARASIRIWARDENA, D.; XING, B. Comparison of natural organic acids and synthetic chelates at enhancing phytoextraction of metals from a multi-metal contaminated soil. Environmental Pollution, Barking, v. 140, n. 1, p. 114-123, 2006.

PEREIRA, J. C.; GUIMARÃES-SILVA, A. K.; NALINI JÚNIOR, A.; PACHECO, S. E.; LENA, J. C. Distribuição, fracionamento e mobilidade de elementos traço em sedimentos superficiais. Química Nova, São Paulo, v. 30, n. 5, p. 1249-1255, 2007.

RABINOWITZ, M.; LEVITON, A.; NEEDLEMAN, H. Lead in milk and infant blood: a dose-response model. Archives of Environmental Health, Washington, v. 40, n. 5, p. 283-286, 1985.

RATTAN, R. K.; DATTA, S. P.; CHHONKAR, P. K.; SURIBABU, K.; SINGH, A. K. Long-term impact of irrigation with sewage effluents on heavy metal content in soils, crops and groundwater-a case study. Agriculture, Ecosystem \& Environment, v. 109, n. 3-4, p. 310-322, 2005.

SARMA, M.; HANDIQUE, G. K.; HANDIQUE, A. K. Toxic heavy metal stress in paddy: metal accumulation profile and development of a novel stress protein in seed. Indian Journal of Plant Physiology, Delhi, v. 11, n. 3, p. 227-233, 2006.

SHARMA, P.; DUBEY, R. S. Toxic metals in: lead toxicity in plants. Brazilian Journal Plant Physiology, Londrina, v. 17, n. 1, p. 35-52, 2005.

SINHA, P.; DUBE, B. K.; SRIVASTAVA, P.; CHATTERJEE, C. Alteration in uptake and translocation of essential nutrients in cabbage by excess lead, Chemosphere, Oxford, v. 65, n. 4, p. 651-656, 2006.

WANG, G.; SU, M. Y.; CHEN, Y. H.; LIN, F. F.; LUO, D.; GAO, S. F. Transfer characteristics of cadmium and lead from soil to the edible parts of six vegetable species in southeastern China. Environmental Pollution, Barking, v. 144, n. 1, p. 127-135, 2006.

WORLD HEALTH ORGANIZATION - WHO. Evaluation of certain food additives and contaminants ( $41^{\text {st }}$ Report of the Joint FAO/WHO Expert Committee on Food Additives). Geneva: World Health Organization, 1993. (WHO Technical Report Series, n. 837).

YADAV, R. K.; GOYAL, B.; SHARMA, R. K.; DUBEY, S. K.; MINHAS, P. S. Post-irrigation impact of domestic sewage effluent on composition of soils, crops and ground water-a case study. Environment International, Elmsford, v. 28, n. 6, p. 481-486, 2002. 
